\title{
Analysis of capital buffers in Serbia
}

\section{Анализа заштитних слојева капитала у Србији}

\section{Vesna Martin}

National Bank of Serbia, Belgrade, Republic of Serbia, martinv0803@hotmail.com

\begin{abstract}
The aim of this paper is to analyse all capital buffers that are currently applied in Serbia. Regulation that transposes Basel III regulatory standards in Serbia was adopted in December 2016. These buffers increase the resilience of banks to losses, reduce excessive or underestimated exposures and restrict the distribution of capital. An assessment of the long-term trend of the credit-to-GDP ratio is based on using a one-sided HodrickPrescott filter and the selected value of the parameter $\lambda$ equals 400000 . Also, this paper used the following methods of research: inductive and deductive methods, methods of analysis and synthesis, classification method and the method of comparison. Analysis has shown that capital buffers that are currently applied in Serbia are fully harmonized with European Union regulations and international best practices.
\end{abstract}

Keywords: capital buffers, financial stability, macroprudential policy, capital requirement, Basel III JEL classification: E22, E50, E58, G28

\begin{abstract}
Сажетак: Циљ овог рада је анализа свих заштитних слојева капитала који се тренутно примењују у Србији. У децембру 2016. године усвојени су прописи којима су Базел III стандарди уведени у Србији. Увођењем заштитних слојева капитала повећава се отпорност банака на губитке, смањују прекомерне или потцењене изложености и ограничава расподела капитала. Процена одступања учешћа кредита у БДП-у од свог дугорочног тренда заснива се на коришћењу једностраног Hodrick-Prescott филтера и изабрана вредност параметра $\lambda$ износи 400000 . Такође, у овом раду користиће се следеће методе истраживања рада, а то су индуктивне и дедуктивне методе, методе анализе и синтезе, метода класификације и методе упоређивања. Анализа је показала да су заштитни слојеви капитала који се тренутно примењују у Србији у потпуности усклађене са прописима Европске уније и најбољом међународном праксом.
\end{abstract}

Кључне речи: заштини слојеви капитала, финансијска стабилност, макропруденцијална политика, капитални захтеви, Базел III

JEЛ класификација: E22, E50, E58, G28

\section{Introduction}

The need to improve the financial regulatory framework, as well as the lack of instruments that would act on systemic risk have been pointed out during and after the global financial crisis of 2007/2008. According to Annual Financial Stability Report (2019), „,new standards and instruments have been developed and implemented at the global level in order to preserve and strengthen the stability of the financial system“" (p. 14). One of the responses of the shortcomings of the system highlighted by the global financial crisis has been the establishment of adequate regulatory bodies. At the level of the European Union, the European Systemic Risk Board has been established, which is according to Annual Financial Stability Report (2019), „entrusted with the responsibility for macroprudential supervision of the financial system of the European Union and the prevention and mitigation of systemic risk. After the weaknesses of the financial system were identified, 
which manifested during the financial crisis, as well as the shortcomings of the Basel II standards, the process of amending those regulations began" (p. 15).

Capital buffers symbolize one of the key novelties of Basel III standard and represent an "additional Common Equity Tier 1 capital that banks are obliged to maintain above the prescribed regulatory minimum. Capital buffers should limit systemic risks in the financial system, which can be structural (systemic risk buffer and capital buffer for a systemically important bank) or cyclical (capital conservation buffer and countercyclical capital buffer)" (Annual Financial Stability Report, 2019, p. 15). In this regard, a financial stability function has been developed with the aim of limiting the effect of systemic risk in the financial system (Puzanova \& Dullmann, 2013; Tomuleasa, 2015). In the most general case, systemic risk can be defined "as a risk that affects the normal functioning of the entire financial system, and not just individual financial institutions" (Annual Financial Stability Report, 2019, p. 14).

The aim of this paper is to analyse all capital buffers that are currently applied in Serbia. An assessment of the long-term trend of the credit-to-GDP ratio is based on using a one-sided Hodrick-Prescott filter and the selected value of the parameter $\lambda$ equals 400000 . Also, inductive and deductive methods, methods of analysis and synthesis, classification methods, and comparison methods will be used in this paper. This paper is organized in the following way: literature review will be presented in Section 1, while Section 2 deals with the analysis of all capital buffers. Domestic regulation for each capital buffers in Section 2 will be displayed, then indicators for activating and changing their rate, as well as proposals for their improvement. The paper ends with a Conclusion, where all the main points of this paper will be summarized.

\section{Literature review}

The development of macroprudential policy, which is a relatively new regulation, began after the global financial crisis of 2007/2008. This policy includes "activities and measures aimed at preventing the existence of systemic risks, i.e. risk disruption to financial services in the financial system that could pose serious negative consequences for the real economy" (Annual Financial Stability Report, 2019, p. 15). It is a regulation that did not formally exist before 2008, and in that period, in order to limit systemic risks, the states applied the instruments of monetary, microprudential and fiscal policy. Since then macroprudential policy and its instruments have been constantly evolving taking into account preservation and improvement of financial stability as one of the aims for the central bank, together with the achievement of price stability.

In order to increase banks' resilience to losses, as well as to reduce excessively or underestimated exposure and to limit the distribution of capital, capital buffers have been introduced (Abbas et al., 2019). The level of capital requirements influences financial soundness indicators (Ercegovac et al., 2019; Vesić et al., 2019). In good times, banks, in accordance with the recommendation of the Basel Committee on Banking Supervision (BCBS, 2010), create capital reserves that will then be used when the systemic risk materializes (Ayuso et al., 2002; Seidler \& Gersl, 2012). Fonseca \& González (2010) 
indicated in their analysis that banks need to keep capital above minimum set levels due to market discipline, by reason of expectations of quasi-earnings (shareholders are interested that the bank has enough capital to prevent operating losses) and the third reason is the need to adjust to the capital requirements set by the regulator. Higher capital requirements indicate better soundness and safety of a bank (Chen et al., 2014), they are built up in an expansion phase and are used during a recession (Drehmann et al., 2010; Heid \& Krüger, 2011; Montagnoli et al., 2018), increase stability and resilience of financial system (Noreen, Alamdar \& Tariq, 2016) and maintain financial system resilience (Bui et al., 2017). Besides the aforementioned, it is equally important to access the influence of capital buffers on level of risk (especially credit risk), supervisory discipline, impact on insurance buffer, economic growth, and competition between financial institutions (Lindquist, 2003).

The global financial crisis revealed the pro-cyclicality of the financial system and the need to use adequate instruments and regulations. The pro-cyclicality of the financial system influences the decision-making process, risk management, and implications of macroprudential policy (Moudud-U1-Huq, 2019, 2019a). In this respect, it is equally important to analyse the cyclical behaviour of capital buffers and evidence is mixed. According to Jokipii \& Milne (2006), and data for the European Union, there is a significant positive relationship with the business cycle for co-operative and smaller banks, while negative is present for commercial and savings banks. In the case of Colombian banks and period 1996-2010, analysis by García-Suaza, Gómez-González, Pabón and Tenjo-Galarza (2011) indicates a negative co-movement between the business cycle and capital buffers, while for six largest Canadian banks in period 1982-2010 Guidara, Son Lai, Soumaré \& Tchana (2013) concluded that there was positive movement between capital buffers and business cycles. Stolz \& Wedow (2005) found that in the case of German banks (savings and cooperative banks) for the period 1993-2003 capital buffers fluctuate anticyclically over the business cycle.

\section{Capital buffers in Serbia}

The Law on the National Bank of Serbia prescribes how "the National Bank of Serbia contributes to the preservation and strengthening of the financial system of the Republic of Serbia" (p. 1), and accordingly, the National Bank of Serbia Executive Board determines and implements instruments and measures. The National Bank of Serbia has at its disposal all instruments and measures of macroprudential policy that are fully in line with the recommendation of the European Systemic Risk Board on transitional goals and instruments of macroprudential policy (ESRB/2013/1). The National Bank of Serbia consultative document "Macroprudential Framework", published in March 2015, regulates the goals, "instruments, and decision-making process of macroprudential policy and specifies its ultimate goal - to contribute to preserving and strengthening the stability of the financial system by preventing new systemic risks and reducing and eliminating existing ones, ensuring the contribution of the financial system to sustainable economic growth" (Annual Financial Stability Report, 2019, p. 15). 
Figure 1: Capital buffer rates - Common Equity Tier 1 capital as a percentage of total risk exposure amount

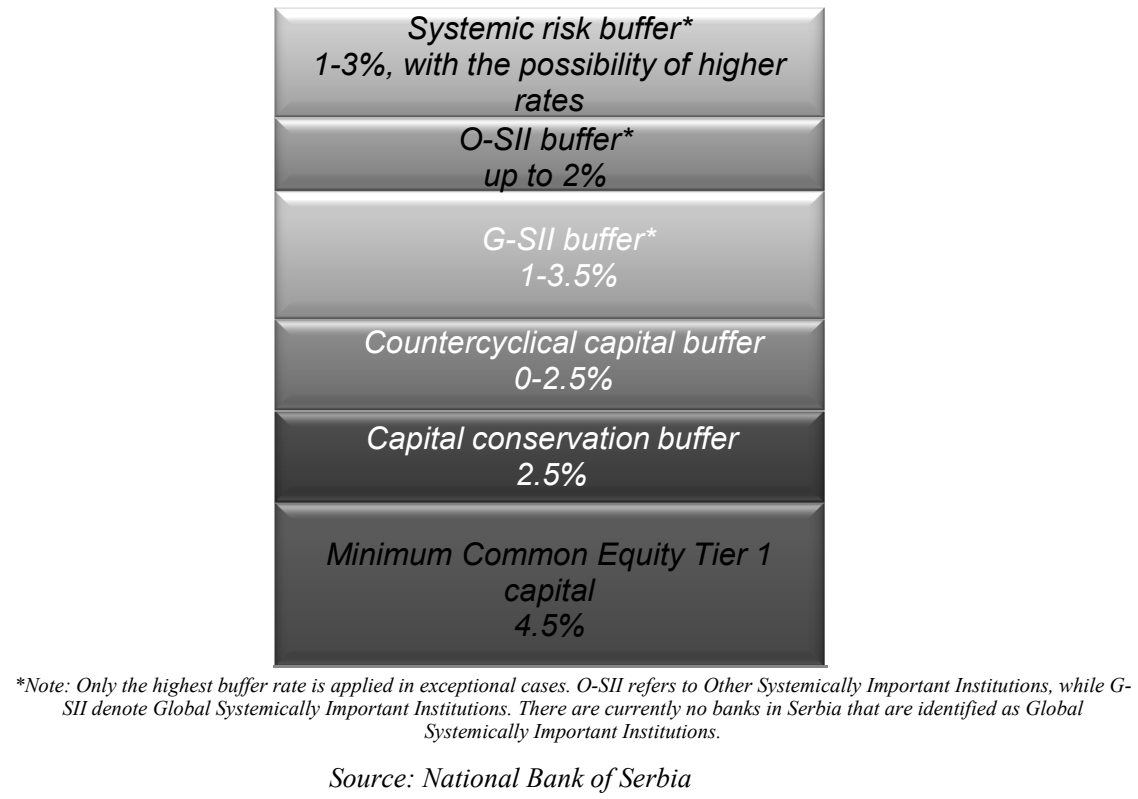

With the adoption of the Decision on Capital Adequacy of the Bank, the Directive 2013/36/EU (CRD IV Directive) was transposed into the domestic regulatory framework which regulates capital buffers. These buffers additionally increased "the resilience of banks to losses, reduced excessive or underestimated exposures, and restricted the distribution of capital. Since June 30, 2017, the following capital buffers are applied in Serbia (Chart 1):

1. systemic risk buffer

2. capital conservation buffer

3. countercyclical capital buffer

4. capital buffer for a systemically important bank" (Annual Financial Stability Report, 2019, p. 16).

\subsection{Systemic risk buffer}

The key risk in the financial system of the Republic of Serbia is the high level of placement and deposit euroisation. The "euroised financial system itself contains a systemic risk that can be realized in case of a sudden depreciation of the domestic currency" (Annual Financial Stability Report, 2019, p. 101). In that case, foreign currency liabilities denominated in domestic currency suddenly increase, and as most borrowers earn their income in domestic currency, this causes a sharp increase in their indebtedness. In this way, due to systemic foreign currency risk, systemic problems with solvency and liquidity of both corporates and households can occur. According to Windischbauer (2016) countries 
with a level of euroisation, both to deposit and placement side, higher than $40 \%$ can be categorized as highly euroised economies, while another study (Álvarez-Plata \& GarcíaHerrero, 2008) concluded that the degree of euroisation between $10 \%$ and $40 \%$ is considered moderate, while the degree of euroisation below $10 \%$ is considered low. Indicators used for assessing the level of euroisation measure the share of "foreign currency and foreign currency-indexed placements in total placements to corporates and households and the share of foreign currency and foreign currency-indexed deposits in total deposits of the corporates and households" (Annual Financial Stability Report, 2019, p. 20-21).

The banking sector of the Republic of Serbia is characterized by a high level of euroisation both of deposits (in December 2020, 59.9\% of total deposits of corporates and households were foreign currency and foreign currency-indexed deposits) and placements (in December 2020, 62.7\% of total placements to corporates and households were foreign currency and foreign currency-indexed placements) - Figures 2 and 3.

Figure 2: Share of foreign currency and foreign currency-indexed deposits in total corporate and household deposits (in \%)

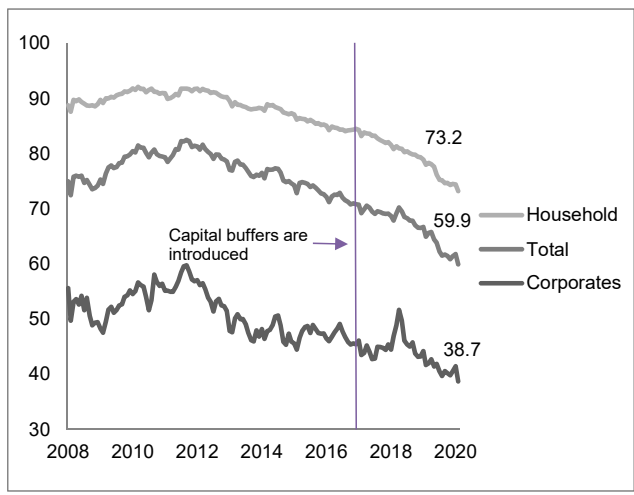

Source: National Bank of Serbia
Figure 3. Share of foreign currency and foreign currency-indexed placements in total corporate and household placements (in \%)

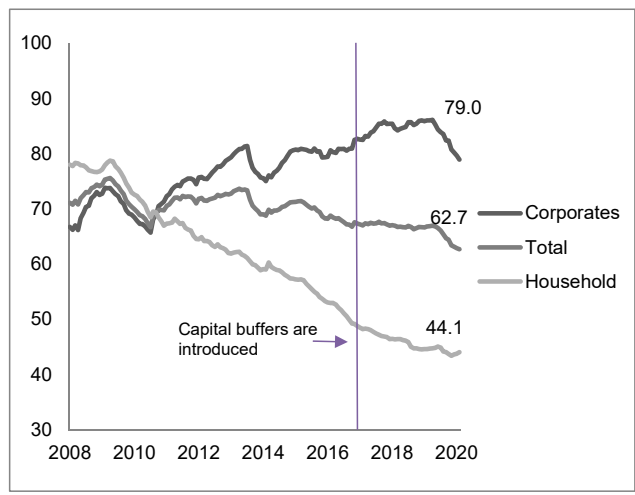

Source: National Bank of Serbia

The systemic risk buffer (hereinafter: SRB) is a macroprudential instrument, which represents additional Common Equity Tier 1 capital that banks are obliged to maintain in order to prevent and mitigate systemic risks of a long-term, non-cyclical nature. In addition to strengthening the resilience of the banking sector to potential shocks, the SRB encourages banks to reduce exposure to identified structural risks, if an exposure-based measure is applied. According to the Decision on the Rate and Manner of Maintaining the Systemic Risk Buffer valid from June 30, 2017, ,all banks whose share of foreign currency and foreign currency-indexed placements to corporates and households in Serbia in the total placement of that bank to corporates and households in Serbia exceeds $10 \%$ are obliged to maintain the SRB equal to 3\% of their total placements of that bank approved to corporates and households in the Republic of Serbia" (Annual Financial Stability Report, 2019, p. 102). The advantage of a unique rate is, among other things, easier communication with banks and the public. The maximum SRB rate does not exist, but the European Union 
Member States are obliged to notify the competent authorities (European Commission, European Systemic Risk Board, European Banking Authority) for rates above 3\% or obtain their opinions. SRB is a flexible instrument and can be implemented in all or certain parts of risk exposure, on domestic exposure or on third-country exposure, on all financial institutions, or on some part of the financial sector (Gabrieli \& Jimborean, 2020).

The basic specificity of the use of the SRB in Serbia relates to the base for calculating capital requirements. While in most other EU countries the SRB is applied to the total risk-weighted bank assets, the base for calculating capital requirements in Serbia is foreign currency and foreign currency-indexed placements of the bank approved to corporates and households in Serbia. In this way, although all banks are required to maintain the same rate (i.e. 3\%), the capital requirements of individual banks vary, depending on their degree of euroisation. With such application of the SRB, banks are directly encouraged to reduce their degree of euroisation, because in the case that the amount of euroised placements is reduced, the amount of capital requirements will also be reduced. It is precisely this way of applying the SRB that the European Systemic Risk Board recognized and recommended to the European Commission, which was subsequently implemented in the Capital Requirements Directive V (Directive EU 2019/878), stating that if the rate is directly applied to the exposures that cause systemic risk, as is the case in Serbia, then it directly affects the limitation of that systemic risk. "On the other hand, by applying SRB to entire risk-weighted bank assets, i.e. without targeting specific exposures, less impact on systemic risk mitigation is achieved" (Annual Financial Stability Report, 2019, p. 56).

„In order to decrease the level of euroisation in the financial system of the Republic of Serbia, the National Bank of Serbia and the Government signed Memorandum on the Strategy of Dinarisation of the Serbian Financial System in April 2012“ (Annual Financial Stability Report, 2019, p. 101). Having in mind that since the dinarisation strategy was introduced nine years ago, macroeconomic stability has been maintained ,,and financial stability strengthened, the Government and the National bank of Serbia signed a new Memorandum on the Dinarisation strategy in December 2018“ (Annual Financial Stability Report, 2019, p. 101). Aware that dinarisation is a gradual and long-term process, the Government and the National bank of Serbia reflected on the achieved results from the measures and activities taken thus far and, based on them, agreed and defined additional measures and activities so as to encourage further dinarisation. The objective of this Strategy is to support greater use of the dinar and reduce foreign currency risk in the domestic financial system.

In the previous period, the National Bank of Serbia applied different measures in order to promote the use of dinar in the financial system. From monetary policy stance following measures are adopted:

1. Only dinar securities without a currency clause can be used as a collateral in the National Bank of Serbia monetary operations, related to open market operations, credit facilities and short-term liquidity loans to banks;

2. According to the Decision on Amending and Supplementing the Decision on Conditions and Manner of Implementing Open Market Operations (2020) „dinar 
securities, without a currency clause, issued by an international financial organization and development bank, or a financial institution which was founded by a foreign state and whose credit rating was set at "AAA" by Standard \& Poor's or Fitch-IBCA, and/or "Aaa" by Moody's, included into the list of collateral for the National Bank of Serbia monetary operations (beside dinar securities, without a currency clause issued by the National Bank of Serbia and Republic of Serbia)" (p. 2);

3. By means of required reserves, the National Bank of Serbia promotes the use of dinar by differentiating required reserves rate on dinar vs. foreign exchange sources of funding. At the moment required reserve ratios are $5 \% / 0 \%$ on dinar sources vs. $20 \% / 13 \%$ on foreign currency sources up (depending on the maturity of sources) and $100 \%$ on foreign currency-indexed liabilities in dinars.

From financial stability perspective, the following measures were applied in order to promote dinar lending and mitigated the risks arising from excessive use of the currency clause:

1. The LTV (loan to value) limit of $80 \%$ was introduced for mortgage loans indexed in foreign currency. The LTV limit is applied only to foreign currency and foreign currency - indexed loans, while dinar loans are exempt from its application in order to stimulate long-term dinar lending;

2. Loans to natural persons may be indexed only to euro. This measure was introduced in order to limit systemic foreign currency risk stemming from the use of currencies other than the euro;

3. The introduction of mandatory downpayment by borrowers in the amount of $30 \%$ for all foreign currency-indexed or foreign currency loans that do not relate to housing loans and credit cards, while all dinar loans are excluded from this measure.

\subsection{Capital conservation buffer}

The aim of applying a capital conservation buffer is to preserve the bank's capital. In the case that a bank breaches this buffer, automatic protection measures are applied in order to limit the payment of dividends and bonuses to that bank. Basel Committee of Banking Supervision prescribed that banks are in obligation to introduce capital conservation buffer in the phase-out process. According to Basel III in January 2016 capital conservation buffer was set at the level of " $0.625 \%$ of risk-weighted assets and then increased by $0.625 \mathrm{pp}$ at the beginning of each following year, reaching 2.5\% of risk-weighted assets" (Annual Financial Stability Report, 2019, p. 56) at the beginning of January 2019.

According to section 434 of the Decision on Capital Adequacy (2021), banks in Serbia are "obliged to maintain a capital conservation buffer on an individual and consolidated basis equal to $2.5 \%$ of their risk-weighted assets" (p. 335). The capital conservation buffer may consist only of Common Equity Tier 1 capital and applies in Serbia as of 30 June 2017. Since its introduction capital conservation buffer in Serbia is set at the level of $2.5 \%$ of risk-weighted assets. 


\subsection{Countercyclical capital buffer}

"Countercyclical Capital Buffer (hereinafter: CCyB) is a macroprudential instrument used for mitigating the procyclicality of the financial system. CCyB represents an additional buffer of Common Equity Tier 1 capital above the prescribed regulatory minimum that a bank maintains to prevent and mitigate long-term, cyclical systemic risks" (Annual Financial Stability Report, 2019, p. 53). According to the Decision on Capital Adequacy of Banks (2021) the National Bank of Serbia sets the CCyB rate for the Republic of Serbia "on a quarterly basis, taking into account:

(1) Reference indicator based on the difference between the credit-to-GDP ratio and its long-run trend (credit gap in GDP), which is calculated on a quarterly basis, in line with the recommendations of the European Systemic Risk Board regarding the method of measuring and calculating difference between the credit-to-GDP ratio and its long-run trend;

(2) Valid recommendations of the European Systemic Risk Board and any recommendations of that Board regarding the determination of the $\mathrm{CCyB}$ rate;

(3) Other indicators it considers relevant to monitoring the cyclical dimension of systemic risk" (p. 336).

\section{Figure 4: Credit-to-GDP ratio and its long run trend}

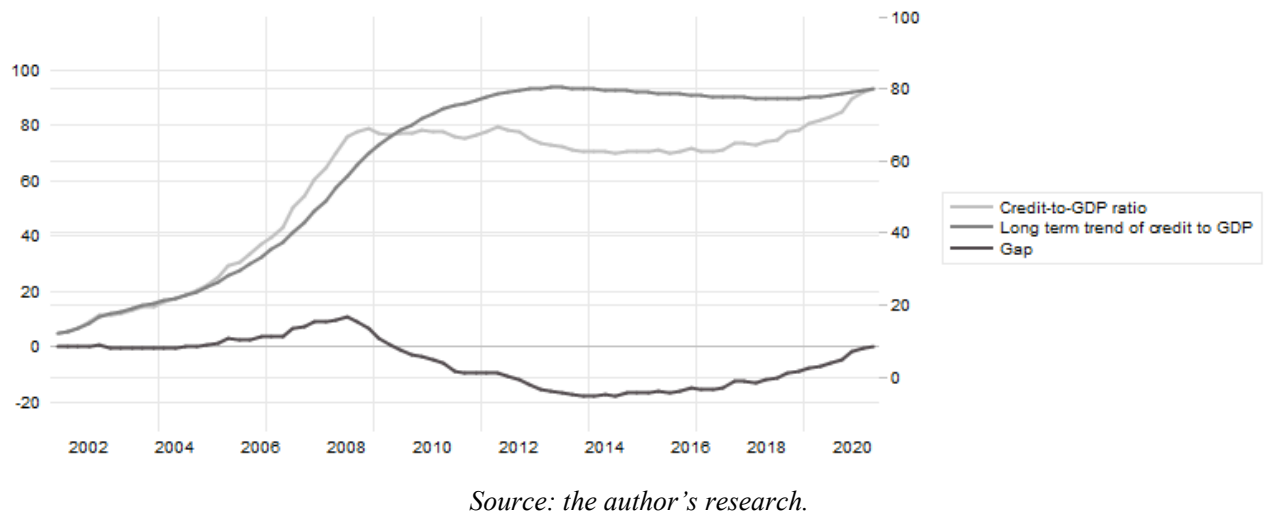

The CCyB rate is determined on the basis of an expert assessment as a combination of analysis on reference indicators and additional optional indicators. The main indicator of excessive credit activity is the share of the credit gap in GDP. Empirical research, done by Drehmann \& Tsatsaronis (2014), has shown that this is one of the most reliable indicators for the early prediction of an upcoming financial crisis. CCyB is introduced in order for regulators to increase capital requirements during the credit expansion period (Castro, 2020). Credit growth is considered excessive if the credit-to-GDP ratio is greater by a minimum of $2 \mathrm{pp}$ than its long-term trend, and the credit growth rate does not support economic growth. The long-term trend of the credit-to-GDP ratio is estimated using a one-sided Hodrick-Prescott (HP) filter. HP filter is a mathematical tool used in macroeconomics to evaluate the trend of variables over time. A one-sided, 
recursive, HP filter for trend calculation uses only the information available at the observed time. In order to determine the long-term trend of GDP, the selected value of the parameter $\lambda$ equals 400000 (Figure 4).

According to the Decision on Capital Adequacy of Banks (2021) "CCyB rate for the Republic of Serbia ranges between $0 \%$ and $2.5 \%$ of the bank's risk-weighted assets, setting the rate in steps of $0.25 \mathrm{pp}$ or multiples of 0.25 pp" (p. 336), which is in line with Basel III standard. Since its introduction $\mathrm{CCyB}$ is set at the level of $0 \%$. According to the Explanation of the countercyclical capital buffer rate for the Republic of Serbia (2021) "at its meeting in March 2021, the Executive Board decided to keep the countercyclical capital buffer rate at $0 \%$, considering the following:

- guide for setting the $\mathrm{CCyB}$ rate: $0 \%$;

- credit-to-GDP ratio: $80.2 \%$;

- deviation of credit-to-GDP ratio from its long-term trend (credit-to-GDP gap): -0.04 pp" (p. 2).

According to the Expert Group of the European Systemic Risk Board, it is allowed that additional indicators be selected from country to country (Detken et al., 2014). Besides the credit-to-GDP gap from its long-term trend, additional optional indicators are taken into account for the purpose of setting the $\mathrm{CCyB}$ rate for Serbia such as the real estate market (real estate DOMex index and indices of the number of newly issued building permits), external imbalance (current account deficit and net foreign direct investments) and main banking sector indicators (capital adequacy ratio, non-performing loans and loan-todeposit). The analysis of the reference indicator and additional indicators points to sustainable lending activity. Given that the estimated credit-to-GDP gap is still below its long-term trend, i.e. that this deviation is below the reference value of $2 \mathrm{pp}$, the CCyB rate for the Republic of Serbia was maintained at $0 \%$, in order to mitigate the potential negative consequences of the pandemic on the financing of the corporates and households.

In order to improve $\mathrm{CCyB}$ we can propose the following suggestions:

1. In the case of emerging market economies with a more volatile behaviour, such as Serbia, the parameter value $\lambda$ of 1600 could be alternatively used in order to monitor higher frequency movements in the credit cycle which can be significant.

2. It is recommended to use the Vulnerabilities Barometer, as part of the monitoring framework for cyclical risks. This could improve quantitative tools for the timely and adequate introduction and release of the $\mathrm{CCyB}$ rate as well as indicators that could point to risk accumulation in the financial system. Duprey \& Roberts (2017) make an analysis of using the Vulnerabilities Barometer in the case of the Bank of Canada to measure financial system vulnerabilities.

3. The credit activity should be forecasted for the Republic of Serbia in order to assess the trend of the reference indicator and the moment of introduction or relaxation of the CCyB rate.

4. It is recommended that a Dashboard/Heatmap with clear alert and signalling thresholds are developed.

5. Recent analyses have found that a one-sided HP filter suffers from major ex-post revisions, although the Basel III regulations explicitly prescribe the use of a one-sided 
HP filter. Edge and Meisenzahl (2011) and Alessandri, Bologna, Fiori and Sette (2015) have indicated in their analysis that the credit gap assessment based on a one-sided HP filter is subject to significant ex-post audits and thus has a major impact on the macroprudential policy decision. Thus, the "false positive" share of credit activity in GDP would affect the unnecessary tightening of this capital requirement. On the other hand, authors such as Darracq Pariès, Fahr and Kok (2019) suggest that the credit-toGDP gap could be downward, after prolonged credit growth, to the extent that this growth causes an increase in bias in the estimated trend component. Based on an analysis by Alessandri, Bologna and Galardo (2021), it is recommended to assess the gap between credit and GDP from its long-term trend using a two-sided HP filter.

\subsection{Capital buffer for a systemically important bank}

Systemically important financial institutions are financial institutions whose liquidation or bankruptcy can jeopardize the functioning of part or the entire financial system. The risks affecting these institutions grow into the systemic risks of the financial system. For this reason, it is necessary to take measures regarding the special treatment of these institutions in relation to other institutions, given their importance for the stability of the entire financial system. The bankruptcy of Lehman Brothers in September 2008 and American Insurance Group (AIG) bailed during the global financial crises in 2008 have indicated how single financial intuition can influence the entire financial system (Co-Pierre, 2011).

Table 1: The list of systemically important banks in the Republic of Serbia and rates of the capital buffer rates for systemically important banks

\begin{tabular}{|c|c|}
\hline Bank & $\begin{array}{r}\text { Capital buffer rate for } \\
\text { systemically important banks }\end{array}$ \\
\hline Baca Intesa & $2 \%$ \\
Unicredit Bank & $2 \%$ \\
Komercijalna banka & $2 \%$ \\
OTP banka & $1 \%$ \\
Raiffeisen banka & $1 \%$ \\
Erste Bank & $1 \%$ \\
Banka Poštanska Štedionica & $1 \%$ \\
AIK bank & $1 \%$ \\
Vojvođanska banka & $1 \%$ \\
\hline
\end{tabular}

Source: National Bank of Serbia

Banks determined by the National Bank of Serbia as being systemically important for the domestic economy (based on the following criteria: the "size of a bank, the importance for the economy, the importance of the cross-border activity of a bank, the interconnectedness of a bank with the financial system, substitutability of a bank in the financial system or the complexity of a bank") (Decision on Capital Adequacy of Banks, 2021 , p. 344) are obliged to maintain additional capital equal to $1 \%$ or $2 \%$ of their riskweighted assets. The criteria and the method of their fulfilment are the basis of the 
methodology for identifying systemically important financial institutions. According to the Decision on Capital Adequacy of Banks (2021) "the National Bank of Serbia reviews the capital buffer for systemically important banks and the methodology for identification of systemically important banks at least annually" (p. 344) and the last revision was in June 2020 (Table 1).

Capital Requirements Directive V requires that systemically important banks, on a consolidated, subconsolidated or individual basis, maintain a capital buffer for a systemically important bank of up to $3 \%$ of the total risk exposure amount, taking into account the criteria for the identification of the systemically important banks. That buffer shall consist of Common Equity Tier 1 capital. Taking into account this requirement in forthcoming period for the systemically important bank the possibility that Serbia uses capital buffer for a systemically important bank up to $3 \%$ of the total risk exposure can be analysed.

\section{Conclusion}

The global crisis 2007/2008 has highlighted the shortcomings of existing regulations and the need to introduce new ones in order to maintain and improve financial stability and create adequate instruments in the fight against systemic risk. Systemic risk is a risk that threatens the normal functioning of the entire financial system and due to its limitation, the function of financial stability has been developed. "One of the novelties introduced by the implementation of the Basel III standard refers to the introduction of capital buffers, which represent an additional Common Equity Tier 1 capital that banks are obliged to maintain above the prescribed regulatory minimum" (Annual Financial Stability Report, 2019, p. 15).

The capital buffers applied from June 2017 in Serbia are systemic risk buffer, capital conservation buffer, countercyclical capital buffer, and capital buffer for a systemically important bank. Systemic risk buffer is a capital buffer introduced to limit the high degree of euroisation, which increases the financial system's exposure to foreign exchange risk so that the exchange rate channel is one of the main channels of risk spillover to the financial system and real economy. Capital conservation buffer is applied to preserve the bank's capital and countercyclical capital buffer to prevent unsustainable credit growth that is not supported by economic growth. Capital buffer for a systemically important bank is used for identifying systemically important institutions whose liquidation or bankruptcy can jeopardize the functioning of parts or the entire financial system. The analysis showed that all capital buffers currently applied in Serbia have harmonized with the regulations of the European Union and the best international practice.

In addition to the application of capital buffers, in order to assess the vulnerability and resilience of the financial system, the National Bank of Serbia develops and uses various tools to adequately monitor and timely indicate systemic risks. In addition, the National Bank of Serbia conducts quarterly macroprudential stress tests of the banking sector, the aggregate results of which are made public within the Annual Financial Stability Report, providing information related to stress tests, as well as assumptions used, 
projections of positions at the banking sector level and finally the effects on bank capitalization. This greatly contributes to strengthening confidence in the domestic financial system, but also to the transparency and accountability of the National Bank of Serbia in implementing its legal objectives. All this additionally contributes to the strengthening of financial stability, which, in addition to price stability, is a legally defined goal of the National Bank of Serbia.

\section{References}

Abbas, F., Butt, S., Masood, O. \& Javaria, K. (2019). The effect of bank capital buffer on bank risk and net interest margin: evidence from the US. Global Journal of Social Sciences Studies, 5(2), 72-87. Doi: https://doi.org/10.20448/807.5.2.72.87

Alessandri, P., Bologna, P. \& Galardo, M. (2021). Financial crises, macroprudential policy and the reliability of credit-to-GDP gaps. European Systemic Risk Board, 114, 1-47. Doi: https://dx.doi.org/10.2139/ssrn.3659989

Alessandri, P., Bologna, P., Fiori, R. \& Sette, E. (2015). A note on the implementation of the countercyclical capital buffer in Italy. Bank of Italy, 278, 1-38. Doi: https://dx.doi.org/10.2139/ssrn.2649949

Álvarez-Plata, P., \& García-Herrero, A. (2008). To dollarize or de-dollarize: consequences for monetary policy. German Institute for Economic Research (DIW) and BBVA, 0808, 134. Doi: https://dx.doi.org/10.2139/ssrn.1428828

Ayuso, J., Pérez D. \& Saurina, J. (2002). Are capital buffers pro-cyclical? Evidence from Spanish panel data. Banco de España, 1-21.

Basel Committee on Banking Supervision. (2010, September 10). Consultative Document: Countercyclical capital buffer proposal. Retrieved April 10, 2021, from https://www.bis.org/publ/bcbs172.pdf

Bui, C., Scheule, H. \& Wu, E. (2017). The value of bank capital buffers in maintaining financial system resilience. Journal of Financial Stability, 33, 23-40. Doi: https://doi.org/10.1016/j.jfs.2017.10.006

Castro, M. F. (2020). Quantitative analysis of the countercyclical capital buffer. Federal Reserve Bank of St. Louis, Working Paper 2019-008D, 1-50. Doi: https://doi.org/10.20955/wp.2019.008

Chen, Y. K., Ho, A. Y. F. \& Hsu, C.-L. (2014). Are bank capital buffers cyclical? Evidence of developed and developing countries. Journal of Financial Studies, 22(3), 27-56. Doi: https://doi.org/https://doi.org/10.6545/JFS.2014.22(3).2

Co-Pierre, G. (2011). III and systemic risk regulation - what way forward?. University of Jena and University of Halle-Wittenberg, Working Papers on Global Financial Markets No. $17,1-25$.

Darracq Pariès, M., Fahr. S. \& Kok, C. (2019, May). Macroprudential space and current policy trade-offs in the euro area. European Central Bank Financial Stability Review, 
Retrieved April 4, 2021, from https://www.ecb.europa.eu/pub/financialstability/fsr/special/html/ecb.fsrart201905_3 f3ff5a969e.en.html

Decision on Amending and Supplementing the Decision on Conditions and Manner of Implementing Open Market Operations (RS Official Gazette, Nos 45/2011, 34/2013, $74 / 2020$ and 98/2020)

Decision on Capital Adequacy of Banks (RS Official Gazette, Nos 103/2016, 103/2018, 88/2019, 67/2020, 98/2020, 137/2020 and 59/2021)

Decision on the Rate and Manner of Maintaining the Systemic Risk Buffer (RS Official Gazette, No. 58/2017 and 3/2018)

Detken, C., Weeken, L., Alessi, L., Bonfim, D., Boucinha, M., Castro, C., et al. (2014). Operationalising the countercyclical capital buffer: indicator selection, threshold identification and calibration options. European Systemic Risk Board, ESRB Occasional Paper Series, No. 5, 1-95.

Drehmann, M., \& Tsatsaronis, K. (2014). The credit-to-GDP gap and countercyclical capital buffers: questions and answers. BIS Quarterly Review, 55-73.

Drehmann, M., Borio, C., Gambacorta, L., Jiménez, G. \& Trucharte, C. (2010). Countercyclical capital buffers: exploring options. Bank for International Settlements, Working Papers No 317, 1-64. Doi: https://dx.doi.org/10.2139/ssrn.1648946

Duprey, T., \& Roberts, T. (2017). A barometer of Canadian financial system vulnerabilities. Bank of Canada, 2017-24, 1-17.

Edge, M. R., \& Meisenzahl, R. R. (2011). The unreliability of credit-to-GDP ratio gaps in real-time: Implications for countercyclical capital buffers. International Journal of Central Banking, 7(4), 261-298. Doi: https://dx.doi.org/10.2139/ssrn.1956719

Ercegovac, D., Vlaović-Begović, S. \& Jovin, S. (2019). The analysis of the key indicators of the Republic of Serbia banking sector. Anali Ekonomskog Fakulteta u Subotici, 55(41), 81-94. Doi: https://doi.org/10.5937/AnEkSub1941081E

European Systemic Risk Board. (2013, April 4). Recommendation of the European Systemic Risk Board of 4 April 2013 on Intermediate Objectives and Instruments of MacroPrudential Policy (ESRB/2013/1). Retrieved April 3, 2021, from https://www.esrb.europa.eu/pub/pdf/recommendations/ESRB_2013_1.en.pdf?b3291f19e4a 37b5bab77b657df7ec97d

Fonseca, A. R., \& González, F. (2010). How bank capital buffers vary across countries. The influence of cost of deposits, market power and bank regulation. Journal of Banking \& Finance, 34(4), 892-902. Doi: https://doi.org/10.1016/j.jbankfin.2009.09.020

Gabrieli, S. \& Jimborean, R. (2020). Systemic risk buffer: what would this instrument be used for?. Bulletin de la Banque de France, 227/2, 1-11.

García-Suaza, A. F., Gómez-González, J. E., Pabón, A. M. \& Tenjo-Galarza, F. (2011). The cyclical behaviour of bank capital buffers in an emerging economy: size does matter. 
Economic

Modelling,

$29(5)$

1612-1617.

Doi:

https://doi.org/10.1016/j.econmod.2012.05.021

Guidara, A., Son Lai, V., Soumaré, I. \& Tchana, T. F. (2013). Banks’ capital buffer, risk and performance in the Canadian banking system: impact of business cycles and regulatory changes. Munich Personal RePEc Archive. Paper No. 44105, 1-45.

Heid, F., \& Krüger, U. (2011). Do capital buffers mitigate volatility of bank lending? A simulation study. Deutsche Bundesbank, Discussion Paper Series 2: Banking and Financial Studies No 03/2011, 1-22.

Jokipii, T., \& Milne, A. (2006). The cyclical behaviour of European bank capital buffers. Bank of Finland. Research Discussion Papers, No. 17/2006, 1-41.

Law on the National Bank of Serbia (RS Official Gazette, No 72/2003 and its amendments and supplements published in the "RS Official Gazette", Nos 55/2004, 85/2005 - other law, 44/2010, 76/2012, 106/2012, 14/2015 and 40/2015 - Constitutional Court decision and 44/2018)

Lindquist, K.-G. (2003). Banks' buffer capital: How important is risk?. Norges Bank, Working Paper No. 2003/11, 3-19.

Montagnoli, A., Mouratidis, K. \& Whyte, K. (2018). Assessing the cyclical behaviour of bank capital buffers in a finance-augmented macro-economy. The University of Sheffield, 133.

Moudud-Ul-Huq, S. (2019). Banks' capital buffers, risk, and efficiency in emerging economies: are they counter-cyclical?. Eurasian Economic Review, 9, 467-492. Doi: https://doi.org/10.1007/s40822-018-0121-5

Moudud-Ul-Huq, S. (2019a). The impact of business cycle on banks' capital buffer, risk and efficiency: a dynamic GMM approach from a developing economy. Global Business Review, 1-20. Doi: https://doi.org/10.1177\%2F0972150918817382

National Bank of Serbia. (2012, April 6). NBS and Government Sign a Memorandum on Dinarisation Strategy. Retrieved April 2021, https://nbs.rs/en/scripts/showcontent/index.html?id=5675

National Bank of Serbia. (2015, March). Macroprudential Framework. Retrieved April 3, 2021, from https://nbs.rs/export/sites/NBS_site/documents-eng/finansijskastabilnost/macroprudential framework 201503.pdf

National Bank of Serbia. (2018, December). Memorandum on the Dinarisation Strategy. Retrieved April 2, 2021, from https://nbs.rs/export/sites/NBS site/documentseng/publikacije/dinarizacija/Memorandum Dinarisation_Strategy 2018.pdf

National Bank of Serbia. (2019, July). Annul Financial Stability Report 2019. Retrieved April 4, 2021, $\quad$ https://www.nbs.rs/export/sites/NBS site/documentseng/publikacije/fs/fsr 2019.pdf

National Bank of Serbia. (2021, March). Explanation of the countercyclical capital buffer rate for the Republic of Serbia. Retrieved April 4, 2021, 
https://www.nbs.rs/export/sites/NBS site/documents-eng/finansijskastabilnost/Explanation_CCB 20210315.pdf

Noreen, U., Alamdar, F. \& Tariq, T. (2016). Capital buffers and bank risk: empirical study of adjustment of Pakistani banks. International Journal of Economics and Financial Issues, 6(4), 1798-1806.

Puzanova, N. \& Dullmann, K. (2013). Systemic risk contributions: a credit portfolio approach. Journal of Banking \& Finance, 37 (4), 1243-1257. Doi: https://doi.org/10.1016/j.jbankfin.2012.11.017

Seidler, J., \& Gersl, A. (2012). Excessive credit growth and countercyclical capital buffers in Basel III: empirical evidence from central and East European countries. Munich Personal RePEc Archive, Paper No. 43689, 91-107.

Stolz, S. \& Wedow, M. (2005). Banks' regulatory capital buffer and the business cycle: evidence for German savings and cooperative banks. Deutsche Bundesbank, Discussion Paper Series 2: Banking and Financial Studies No 07/2005, 1-48.

The European Parliament and the Council of the European Union. (2013, June 27). Directive 2013/36/EU of the European Parliament and of the Council of 26 June 2013 on access to the activity of credit institutions and the prudential supervision of credit institutions and investment firms, amending Directive 2002/87/EC and repealing Directives 2006/48/EC and 2006/49/EC. Retrieved March 31, 2021, from https://eurlex.europa.eu/LexUriServ/LexUriServ.do?uri=OJ:L:2013:176:0338:0436:EN:PDF

The European Parliament and the Council of the European Union. (2019, May 20). Directive (EU) 2019/878 of the European Parliament and of the Council of 20 May 2019 amending Directive 2013/36/EU as regards exempted entities, financial holding companies, mixed financial holding companies, remuneration, supervisory measures and powers and capital. Retrieved April 1, 2021, from https://eur-lex.europa.eu/legalcontent/EN/TXT/PDF/?uri=CELEX:32019L0878\&from=EN

Tomuleasa, I. (2015). Macroprudential policy and systemic risk: an overview. Procedia Economics and Finance, 20 (2015), 645 - 653. Doi: https://doi.org/10.1016/S22125671(15)00119-7

Vesić, T., Ravić, N. \& Đekić, M. (2019). Comparative analysis of the liquidity ratios of the largest banks of Serbia: Indicator of performance measurement. Anali Ekonomskog Fakulteta u Subotici, 55(42), 3-15. Doi: https://doi.org/10.5937/AnEkSub1942003V

Windischbauer, U. (2016). Strengthening the role of local currencies in EU candidate and potential candidate countries. European Central Bank, 170, 1-51. Doi: https://doi.org/10.2866/140140 
